\title{
Marine sponge Hymeniacidon sp. amphilectane metabolites potently inhibit rat brain microglia thromboxane $B_{2}$ generation
}

\author{
Alejandro M. S. Mayera, Edward Avilés ${ }^{b}$, and Abimael D. Rodríguez ${ }^{b,{ }^{*}}$ \\ aDepartment of Pharmacology, Chicago College of Osteopathic Medicine, Midwestern University, \\ 555 31st Street, Downers Grove, Illinois 60515, USA \\ bDepartment of Chemistry, University of Puerto Rico, P.O. Box 23346, UPR Station, San Juan, \\ Puerto Rico 00931-3346, USA
}

\begin{abstract}
The effects of five Hymeniacidon sp. amphilectane metabolites (1-5) and two semi-synthetic analogs $(\mathbf{6}$ and 7$)$ on thromboxane $\mathrm{B}_{2}\left(\mathrm{TXB}_{2}\right)$ and superoxide anion $\left(\mathrm{O}_{2}{ }^{-}\right)$generation from $E$. coli LPS-activated rat brain microglia were investigated. All Hymeniacidon sp. metabolites and analogs potently inhibited $\mathrm{TXB}_{2}\left(\mathrm{IC}_{50}=0.20-4.69 \mu \mathrm{M}\right)$ with low lactate dehydrogenase release and minimal mitochondrial dehydrogenase inhibition. While a lack of $\mathrm{O}_{2}{ }^{-}$inhibition would suggest that Hymeniacidon sp. metabolites and derivatives inhibit $\mathrm{TXB}_{2}$ synthesis by a cyclooxygenase-dependent mechanism, their pharmacologic potency and limited in vitro cytotoxicity warrants further investigation to develop them as lead compounds to modulate enhanced $\mathrm{TBX}_{2}$ release by activated microglia in neuroinflammatory disorders.
\end{abstract}

\section{Keywords}

marine; diterpene; microglia; neuroinflammation; thromboxane B2

\section{Introduction}

Neuroinflammation, a complex disease process involved in the pathology of several human brain diseases, including Alzheimer's and Parkinson's disease, multiple sclerosis, ischemic stroke, HIV-dementia, trauma and infections, has been hypothesized to involve activated microglia. ${ }^{1}$ Microglia are central nervous system mononuclear phagocytes which respond to neuropathological conditions by becoming activated and releasing large amounts of proinflammatory and potentially neurotoxic mediators, i.e. proteolytic enzymes, reactive oxygen intermediates, cytokines and eicosanoids. ${ }^{2}$ Increased release of the superoxide anion $\left(\mathrm{O}_{2}{ }^{-}\right)$and the eicosanoid thromboxane $\mathrm{A}_{2}\left(\mathrm{TXA}_{2}\right)$, an arachidonic acid metabolite which is a vasoconstrictor and platelet aggregator ${ }^{3}$, have been observed in activated microglia ${ }^{4}$ as well as in neural trauma ${ }^{5}$ and neuroinflammation. ${ }^{6}$ Thus, the reduction or modulation of

(C) 2011 Elsevier Ltd. All rights reserved.

*Corresponding author. AMAYER@midwestern.edu (A.M.S. Mayer), eaviles83@gmail.com (E. Avilés), abrodriguez@uprrp.edu (A.D. Rodríguez).

Supplementary material Copies of the NMR spectra $\left({ }^{1} \mathrm{H}\right.$ and $\left.{ }^{13} \mathrm{C}\right)$ of compounds $1-7$ and Figure 2 can be found in the online version.

Publisher's Disclaimer: This is a PDF file of an unedited manuscript that has been accepted for publication. As a service to our customers we are providing this early version of the manuscript. The manuscript will undergo copyediting, typesetting, and review of the resulting proof before it is published in its final citable form. Please note that during the production process errors may be discovered which could affect the content, and all legal disclaimers that apply to the journal pertain. 
excessive $\mathrm{O}_{2}{ }^{-}$and $\mathrm{TXB}_{2}$ generation by activated microglia has been hypothesized to contribute to the treatment and resolution of neuroinflammatory disorders. ${ }^{2}$ Natural products isolated from marine sponges, in particular those diterpenes based on the amphilectane carbon skeleton bearing an isocyanide functionality, have been identified as potentially useful antimalarial metabolites. ${ }^{7}$ An increasing number of such molecules have also been reported to express antimicrobial,,${ }^{8}$ antifungal, ${ }^{9}$ cytotoxic,,${ }^{10}$ and antifouling activity. ${ }^{11}$ Amphilectane-based diterpene isocyanides, on the other hand, which are typically isolated from sponges belonging to the order Halichondrida, are yet to be investigated as antiinflammatory agents.

\section{Results and discussion}

The Caribbean marine sponge Hymeniacidon sp. was collected at Cabo Norte, Isla de Mona, at a depth of 89 feet during the summer of 2006. After the frozen sponge specimen was lyophilized, it was blended with a 1:1 mixture of $\mathrm{CHCl}_{3}-\mathrm{MeOH}$ and filtered in vacuo. The crude extract was concentrated and stored under vacuum to yield an orange thick paste (28.2 g) that was partitioned with hexane $(4 \times 500 \mathrm{~mL})$ against $\mathrm{H}_{2} \mathrm{O}(1 \times \mathrm{L})$. Preliminary bioassay screenings of the crude extract showed strong biological activity against Plasmodium falciparum $\left(\mathrm{IC}_{50}<0.08 \mu \mathrm{g} / \mathrm{mL}\right.$ ) and Mycobacterium tuberculosis (MIC $<16 \mu \mathrm{g} / \mathrm{mL}$ ). The hexane extract was purified by normal phase $\mathrm{Si}$ gel column chromatography using a gradient of increasing polarity of hexane-EtOAc $(2 \%-50 \%)$ to afford the known diterpene isocyanides 7-isocyano-11(20)-15(16)-amphilectadiene (1), ${ }^{12}$ (-)-8,15-diisocyano-11(20)amphilectene (2), ${ }^{13}$ 7,15-diisocyano-11(20)-amphilectene (3), ${ }^{12} 8$-isocyano-11(20)-ene-15amphilectaformamide (4), ${ }^{13}$ and monamphilectine A (5). ${ }^{14}$

Compounds 1-5 were screened for anti-neuroinflammatory activity in E. coli lipopolysaccharide-activated rat brain microglia in vitro, specifically for thromboxane $\mathrm{B}_{2}$ $\left(\mathrm{TXB}_{2}\right)$ and superoxide anion $\left(\mathrm{O}_{2}^{-}\right)$generation inhibition. During the course of this investigation it became clear to us that isocyanide amphilectanes $\mathbf{2}$ and $\mathbf{3}$ are in fact potent anti-neuroinflammatory agents. In order to reveal the basic structural features required for these marine diterpenes to display their biological activity, we sought to modify the molecular structure of the more abundant compound 2.

Specifically, we wanted to scrutinize the plausible structure-activity relationships of $\mathbf{2}$ by modifying the isocyanide groups at C-8 and C-15 as well as its exocyclic alkene functionality at C-11(20). Thus, we hydrolyzed the isocyanide groups of $\mathbf{2}$ to the corresponding formamides and, in a separate experiment, oxidatively cleaved the exocyclic double bond of $\mathbf{2}$ upon ozonolysis. The structures of derivatives $\mathbf{6}$ and 7, which were prepared using well-established procedures as shown in Scheme 1, were unambiguously demonstrated by a combination of IR, NMR $\left({ }^{1} \mathrm{H}\right.$ and $\left.{ }^{13} \mathrm{C}\right)$ and mass spectrometric measurements of the purified compounds. Inspection of the NMR data indicated that 7 actually consisted of an inseparable mixture of all of the four possible rotational isomers 7ad (Scheme 2).

Derivatives 6 and 7 along with natural products 1-5 were screened in order to determine the effect of these compounds on E. coli LPS-activated microglia $\mathrm{TXB}_{2}$ and $\mathrm{O}_{2}{ }^{-}$generation in vitro. $\mathrm{O}_{2}{ }^{-}$and $\mathrm{TXB}_{2}$ release, as well as short and long term cell viability, were assessed as described in Methods. As shown in Table 1 and supplementary Figure 2A, the results were as follows: all Hymeniacidon sp. metabolites and analogs prepared (1-7) potently inhibited $\mathrm{TXB}_{2}$ generation $\left(\mathrm{IC}_{50}=0.20-4.69 \mu \mathrm{M}\right)$ but demonstrated minimal effect on $\mathrm{O}_{2}-$ release $\left(\mathrm{IC}_{50}>10 \mu \mathrm{M}\right)$. Furthermore the compounds showed low short-term toxicity $\left(\mathrm{LDH}_{50}\right.$ $>10 \mu \mathrm{M}$, supplementary Figure 2A) and reduced long-term toxicity (WST-1 assay, supplemental Figure 2B). Thus, in our in vitro experimental conditions, it appeared that 
inhibition of microglia $\mathrm{TXB}_{2}$ generation resulted from a pharmacologic rather than a toxic effect of compounds (1-7) on the microglia cells.

\section{Conclusion}

Comparison of the $\mathrm{IC}_{50}$ 's of closely related amphilectane diterpenes $2\left(\mathrm{IC}_{50} \sim 0.23 \mu \mathrm{M}\right)$ and $3\left(\mathrm{IC}_{50} \sim 0.20 \mu \mathrm{M}\right)$ supports the observation that the observed bioactivity is associated with presence of the two isonitrile groups. However, the amphilectane diterpenoid skeleton does play a significant role, as suggested by the comparison between the $\mathrm{IC}_{50}$ 's of these two compounds and derivative $7\left(\mathrm{IC}_{50} \sim 3.14 \mu \mathrm{M}\right)$, whereby each isonitrile group was replaced by a formamide functionality. Within the series of natural products 1-5, analogs possessing an isocyanide functionality at C-15 display the highest anti-neuroinflammatory activity, and the presence of a second isocyanide moiety within the same amphilectane core seems to further potentiate its biological activity. However, substitution at C-15 with bulkier functional groups, as observed in compound $\mathbf{5}$, appear to lower the activity. The presence of an exocyclic alkene at C-11(20) also seems to play a role in potentiating the observed pharmacological activity. Lack of $\mathrm{O}_{2}{ }^{-}$inhibition would appear to suggest that all Hymeniacidon sp. metabolites and their derivatives inhibit $\mathrm{TXB}_{2}$ synthesis through a cyclooxygenase-dependent mechanism. In addition to their pharmacologic effects on enhanced $\mathrm{TXB}_{2}$ generation and their reduced cytotoxic effects, it is perhaps of interest to note that the Hymeniacidon sp. compounds are more potent inhibitors of rat microglia $\mathrm{TXB}_{2}$ generation than acetylsalicylic acid (aspirin) $\left(\mathrm{IC}_{50}=3.12-10.0 \mu \mathrm{M}\right)^{15,16}$ and flurbiprofen (apparent $\left.\mathrm{IC}_{50}=100 \mathrm{nM}\right),{ }^{17}$ which are two clinically used NSAIDS. Thus, taken together, our present results appear to support the hypothesis that marine Hymeniacidon sp. metabolites and derivatives could become lead compounds for the development of novel agents to modulate excessive release of $\mathrm{TXB}_{2}$ by activated microglia cells in neuroinflammatory disorders. This possibility remains to be investigated in in vivo pharmacologic and toxicologic investigations with these compounds.

\section{Methods}

\subsection{General methods}

Optical rotations were obtained with an Autopol IV automatic polarimeter. Infrared spectra were obtained with a Nicolet Magna FT-IR 750 spectrometer. 1D- and 2D-NMR spectra were recorded with a Bruker DRX-500 FT-NMR spectrometer. Mass spectrometric data were generated at the Mass Spectrometry Laboratory of the University of Illinois at UrbanaChampaign. Column chromatography was performed using Si gel (35-75 mesh), and TLC analysis was carried out using glass pre-coated $\mathrm{Si}$ gel plates and the spots were visualized using a UV lamp at $\lambda=254 \mathrm{~nm}$ or by exposure to $\mathrm{I}_{2}$ vapor. All solvents used were either spectral grade or were distilled from glass prior to use. The identification of 1-5 was accomplished through rigorous comparisons with the physical and chemical data previously reported for these compounds. ${ }^{12-14}$ The purity of each test compound was determined by NMR $\left({ }^{1} \mathrm{H}\right.$ and $\left.{ }^{13} \mathrm{C}\right)$ and high resolution mass spectrometric analysis or HPLC (95\%> purity; see Supporting Information).

\subsection{Collection, extraction, and isolation}

Fresh specimens of the sponge Hymeniacidon sp. (Phylum Porifera; Class Demospongiae) were collected by hand using SCUBA at a depth of $89 \mathrm{ft}$ off Mona Island (Cabo Norte), Puerto Rico in July 2006. A voucher specimen (No. IM06-04) is stored at the Chemistry Department of the University of Puerto Rico, Río Piedras Campus. The organism was partially air dried, frozen, and lyophilized prior to its extraction. The dry sponge (200 g) was cut into small pieces and blended using a mixture of $\mathrm{CHCl}_{3}-\mathrm{MeOH}(1: 1)(4 \times 1 \mathrm{~L})$. After 
filtration, the crude extract was concentrated and stored under vacuum to yield an orange thick paste $(28 \mathrm{~g})$ that was suspended in $\mathrm{H}_{2} \mathrm{O}(700 \mathrm{~mL})$ and extracted with $n$-hexane $(4 \times$ $500 \mathrm{~mL}$ ). The resulting hexane extract was concentrated in vacuo to yield $7.6 \mathrm{~g}$ of an orange oil that was purified by Si gel $(170 \mathrm{~g})$ column chromatography using a gradient of increasing polarity with $n$-hexane/EtOAc (98:2-1:1) as mobile phase and separated into 37 fractions on the basis of TLC and ${ }^{1} \mathrm{H}$ NMR analyses. Fraction 4 consisted of a colorless crystalline solid that was subsequently identified as known 7-isocyano-11(20)-15(16)-amphilectadiene (1) $(10.2 \mathrm{mg}, 0.005 \%) .{ }^{12}$ Likewise, fraction 11 consisted of a colorless crystalline solid that was identified as known (-)-8,15-diisocyano-11(20)-amphilectene (2) (528 mg, 0.27\%) after Xray crystallographic analysis. ${ }^{13}$ Fractions 13 and 27 were subsequently identified as known compounds 7,15-diisocyano-11(20)-amphilectene (3) (188.6 mg, 0.09\%) and 8isocyano-11(20)-ene-15-amphilectaformamide (4) (204.3 $\mathrm{mg}, 0.10 \%)$, respectively. ${ }^{12,13}$ Fraction $36(13.1 \mathrm{mg})$ was re-chromatographed over Si gel $(1.0 \mathrm{~g})$ with $20 \%$ EtOAc in $n$ hexane to afford pure monamphilectine A (5) $(3.0 \mathrm{mg}, 0.002 \%) .{ }^{14}$

\subsection{Ozonolysis of (-)-8,15-diisocyano-11(20)-amphilectene (2)}

Crystals of compound $2(20 \mathrm{mg}, 0.062 \mathrm{mmol})$ were dissolved in freshly distilled $\mathrm{MeOH}(20$ $\mathrm{mL}$ ) and the resulting solution was cooled to $-78{ }^{\circ} \mathrm{C}$ and bubbled with $\mathrm{O}_{2} / \mathrm{O}_{3}$ for $2 \mathrm{~min}$. The $\mathrm{O}_{3}$ generator was turned off and $\mathrm{O}_{2}$ was bubbled through the solution to remove excess ozone. The reaction was stirred for another $30 \mathrm{~min}$ before it was allowed to slowly warm up to $25^{\circ} \mathrm{C}$. After evaporation of the solvent, the amorphous solid left over was purified over a short column of Si gel (1.5 g) using 20\% EtOAc/hexane to afford $15.6 \mathrm{mg}(77 \%)$ of 8,15diisocyano-11-amphilectone (6). Although this compound was prepared before by Ciavatta et. al., ${ }^{12}$ the physical and chemical properties of 6 were not described.

4.3.1. 8,15-Diisocyano-11-amphilectone (6)-White solid; [a $]^{20}{ }_{D}-20.3$ (c 1.4, $\mathrm{CHCl}_{3}$ ); IR (neat) $v_{\max } 2968,2925,2870,2127,1714,1460,1444,1371,1166,1149,1116$, $1087,1060,977,914,883 \mathrm{~cm}^{-1} ;{ }^{1} \mathrm{H}$ NMR $\left(\mathrm{CDCl}_{3}, 500 \mathrm{MHz}\right) \delta 2.66(1 \mathrm{H}, \mathrm{td}, J=13.5$ and $6.0 \mathrm{~Hz}, \mathrm{H}-9 \mathrm{a}), 2.42(1 \mathrm{H}, \mathrm{dd}, J=13.7$ and $5.2 \mathrm{~Hz}, \mathrm{H}-10 \mathrm{a}), 2.36(1 \mathrm{H}, \mathrm{t}, J=11.3 \mathrm{~Hz}, \mathrm{H}-12)$, $2.24(1 \mathrm{H}, \mathrm{m}, \mathrm{H}-9 \mathrm{~b}), 2.19(1 \mathrm{H}, \mathrm{dt}, J=13.5$ and $3.5 \mathrm{~Hz}, \mathrm{H}-2 \mathrm{a}), 1.95(1 \mathrm{H}, \mathrm{m}, \mathrm{H}-6 \mathrm{a}), 1.90(1 \mathrm{H}$, m, H-1), $1.51(1 \mathrm{H}, \mathrm{m}, \mathrm{H}-10 \mathrm{~b}), 1.49$ (1H, m, H-6b), 1.47 (1H, m, H-14a), 1.44 (3H, s, H-16), $1.38(1 \mathrm{H}, \mathrm{m}, \mathrm{H}-5 \mathrm{a}), 1.33(3 \mathrm{H}, \mathrm{s}, \mathrm{H}-17), 1.31(1 \mathrm{H}, \mathrm{m}, \mathrm{H}-7), 1.27(1 \mathrm{H}, \mathrm{dd}, J=13.8$ and $9.3 \mathrm{~Hz}$, $\mathrm{H}-14 \mathrm{~b}), 1.19(1 \mathrm{H}, \mathrm{m}, \mathrm{H}-13), 1.11(1 \mathrm{H}, \mathrm{qd}, J=10.7$ and $3.2 \mathrm{~Hz}, \mathrm{H}-4), 0.99(1 \mathrm{H}, \mathrm{m}, \mathrm{H}-3), 0.96$ $(3 \mathrm{H}, \mathrm{d}, J=6.1 \mathrm{~Hz}, \mathrm{H}-19), 0.82(3 \mathrm{H}, \mathrm{d}, J=6.4 \mathrm{~Hz}, \mathrm{H}-18), 0.75(1 \mathrm{H}, \mathrm{m}, \mathrm{H}-2 \mathrm{~b}), 0.74(1 \mathrm{H}, \mathrm{m}$, $\mathrm{H}-5 \mathrm{~b}) ;{ }^{13} \mathrm{C}$ NMR $\left(\mathrm{CDCl}_{3}, 125 \mathrm{MHz}\right) \delta 210.8(\mathrm{C}, \mathrm{C}-11), 157.9$ (C, t, $\left.J=4.3 \mathrm{~Hz}, \mathrm{C}-20\right), 154.2$ $(\mathrm{C}, \mathrm{t}, J=4.6 \mathrm{~Hz}, \mathrm{C}-21), 65.7(\mathrm{C}, \mathrm{t}, J=4.6 \mathrm{~Hz}, \mathrm{C}-8), 56.5(\mathrm{C}, \mathrm{t}, J=4.6 \mathrm{~Hz}, \mathrm{C}-15), 55.0(\mathrm{CH}$, C-13), 53.5 (CH, C-12), $46.7\left(\mathrm{CH}_{2}, \mathrm{C}-14\right), 43.3(\mathrm{CH}, \mathrm{C}-4), 40.4(\mathrm{CH}, \mathrm{C}-7), 40.3\left(\mathrm{CH}_{2}, \mathrm{C}-2\right)$, $38.5\left(\mathrm{CH}_{2}, \mathrm{C}-9\right), 38.2\left(\mathrm{CH}_{2}, \mathrm{C}-10\right), 35.6(\mathrm{CH}, \mathrm{C}-3), 32.2\left(\mathrm{CH}_{3}, \mathrm{C}-17\right), 31.4(\mathrm{CH}, \mathrm{C}-1), 29.7$ $\left(\mathrm{CH}_{2}, \mathrm{C}-6\right), 29.6\left(\mathrm{CH}_{2}, \mathrm{C}-5\right), 28.2\left(\mathrm{CH}_{3}, \mathrm{C}-16\right), 19.6\left(\mathrm{CH}_{3}, \mathrm{C}-18\right), 15.8\left(\mathrm{CH}_{3}, \mathrm{C}-19\right)$; HRESIMS $\mathrm{m} / z[\mathrm{M}+\mathrm{Na}]^{+} 349.2237$ (calcd for $\mathrm{C}_{21} \mathrm{H}_{30} \mathrm{~N}_{2} \mathrm{ONa}, 349.2256$ ). Recrystallization of $\mathbf{6}$ by slow evaporation from acetone gave crystals of excellent quality that were amenable to X-ray crystallographic analysis. The crystallographic data for $\mathbf{6}$ have been deposited at the Cambridge Crystallographic Data Centre, under the reference number CCDC 842072. Copies of the data can be obtained, free of charge, on application to the Director, CCDC, 12 Union Road, Cambridge CB2 1EZ, UK (fax: +44 1223336033 or e-mail: deposit@ccdc.cam.ac.uk).

\subsection{Acid hydrolysis of (-)-8,15-diisocyano-11(20)-amphilectene (2)}

Compound 2 (10 mg, $0.031 \mathrm{mmol})$ was dissolved in freshly distilled $\mathrm{MeOH}(10 \mathrm{~mL})$, after which a few drops of glacial $\mathrm{AcOH}$ were added. The solution was stirred and allowed to stand at $\sim 25^{\circ} \mathrm{C}$ until all of the starting material disappeared on the basis of TLC analysis (24 h). Thereafter, the solvent was removed by vacuum distillation and the resulting solid 
residue was purified by flash $\mathrm{Si}$ gel column chromatography with $5 \% \mathrm{MeOH}\left(\mathrm{NH}_{3}\right) / \mathrm{CHCl}_{3}$ to afford $7.2 \mathrm{mg}(65 \%)$ of 11(20)-ene-8,15-amphilectodiformamide (7). This compound consisted of an inseparable mixture of four rotational isomers about the formamide moieties, i.e. 7a-d (Scheme 2). Thus, a complete assignment of the ${ }^{1} \mathrm{H}$ and ${ }^{13} \mathrm{C}$ NMR signals was not feasible.

4.4.1. 11(20)-ene-8,15-Amphilectodiformamide (7)-Colorless oil; [a $]^{20}{ }_{\mathrm{D}}-18.0(\mathrm{c}$ 1.0, $\mathrm{CHCl}_{3}$ ); IR (neat) $v_{\max } 3294,3080,3055,2964,2935,2916,2856,1676,1531,1456$, $1384,1317,1267,891,754,665 \mathrm{~cm}^{-1}$; HRESIMS $\mathrm{m} / z[\mathrm{M}+\mathrm{H}]^{+} 383.2749$ (calcd for $\left.\mathrm{C}_{22} \mathrm{H}_{36} \mathrm{~N}_{2} \mathrm{O}_{2} \mathrm{Na} 383.2674\right)$.

\subsection{Anti-neuroinflammatory assay}

The experimental protocol to study the effect of Hymeniacidon sp. metabolites and semisynthetic derivatives on microglia release of $\mathrm{O}_{2}{ }^{-}$and $\mathrm{TXB}_{2}$ was as follows. Rat neonatal microglia $\left(2 \times 10^{5}\right.$ cells) were activated in vitro by seeding the cells into each well of 24-well flat-bottom culture clusters and stimulating them with E. coli lipopolysaccharide (LPS) $(0.3 \mathrm{ng} / \mathrm{mL})$ for $17 \mathrm{~h}$ in Dulbecco's modified Eagle medium $+10 \%$ fetal bovine serum $+120 \mathrm{U} / \mathrm{mL}$ penicillin $+12 \mu \mathrm{g} / \mathrm{mL}$ streptomycin in a humidified $5 \% \mathrm{CO}_{2}$ incubator at $35.9^{\circ} \mathrm{C}^{2}$ Media was then removed, microglia washed with warm $\left(37^{\circ} \mathrm{C}\right)$ Hanks' balanced salt solution (HBSS) and then microglia pre-incubated with compounds 1-7 $(0.01-10 \mu \mathrm{M})$ or vehicle (DMSO) for $15 \mathrm{~min}$ prior to stimulation with phorbol 12-myristate 13-acetate (PMA) $(1 \mu \mathrm{M})$ for $70 \mathrm{~min}$. All experimental treatments were run in triplicate and in a final volume of $1 \mathrm{~mL}$. After PMA stimulation HBSS was aspirated from each well and $\mathrm{O}_{2}{ }^{-}$determined via superoxide dismutase-inhibitable reduction of ferri-cytochrome $\mathrm{C}$ and $\mathrm{TXB}_{2}$ by EIA as described. ${ }^{2}$ Table 1 and supplementary Figure $2 \mathrm{~A}$ show data for each compound from 2-4 representative experiments and is expressed as the compound's inhibitory concentration $50 \%\left[\mathrm{IC}_{50}\right]$ for $\mathrm{O}_{2}^{-}$and $\mathrm{TXB}_{2}$ generation.

\subsection{Microglia cell viability assays}

Short-term cell viability (90 min) was assessed by lactate dehydrogenase (LDH) release from microglia as described elsewhere. ${ }^{2}$ Microglia LDH was expressed as percent of total LDH. Total LDH resulted from Triton X-100 (0.1\%)-treated (and 100\% lysed) microglia cells (intracellular LDH) plus LDH released to the extracellular medium. Table 1 and supplementary Figure 2A show data for each compound from 3-4 representative experiments. Long-term cell viability (2.5-19 h) was determined by the WST-1 (4-[3-(4iodophenyl)-2-(4-nitrophenyl)-2H-5-tetrazolio]1,3-benzene disulfonate) colorimetric assay, based on the cleavage of the tetrazolium salt WST-1 (4-[3-(4-iodophenyl)-2-(4nitrophenyl)-2H-5-tetrazolio]1,3-benzene disulfonate) (slightly red) to formazan (red) by mitochondrial dehydrogenases in viable cells. ${ }^{18}$ Briefly, rat neonatal microglia $(10,000$ cells/ well) were plated in LPS-free 96-well cell culture clusters in $0.2 \mathrm{~mL}$ DMEM without FBS containing $120 \mathrm{U} / \mathrm{mL} \mathrm{P}+12 \mu \mathrm{g} / \mathrm{mL} \mathrm{S}$. Thereafter, each well received $2 \mu \mathrm{L}$ of compounds 1-7 $(0.1 \mu \mathrm{M}-10 \mu \mathrm{M}$ final concentration) or vehicle (DMSO) and plates were incubated in a humidified $5 \% \mathrm{CO}_{2}$ incubator at $36^{\circ} \mathrm{C}$ for $18 \mathrm{~h}$. Thereafter, $20 \mu \mathrm{L}$ of the tetrazolium salt WST-1 (Roche Diagnostics Indianapolis, IN) was added to wells, plates were incubated in a humidified $5 \% \mathrm{CO}_{2}$ incubator at $36^{\circ} \mathrm{C}$ for $2 \mathrm{~h}$, and the reduction of the WST-1 reagent to formazan was measured at $450 \mathrm{nM}$ with a reference at $620 \mathrm{nM}$, with a microtiter plate (ELISA) reader. Supplementary Figure 2B illustrates data for compounds 1-7 from one representative experiment in triplicate. 


\subsection{Statistical analysis of the data}

Data were analyzed with the Prism ${ }^{\circledR}$ software package purchased from GraphPad (San Diego, CA.). One-way analysis of variance followed by Dunnett's test was performed on all sets of data. Hymeniacidon sp. metabolites-treated groups were compared with the vehicletreated group, shown as 0 or control in the corresponding figures. Differences were considered statistically significant at $\mathrm{p}<0.05$ and reported in each figure legend.

\section{Supplementary Material}

Refer to Web version on PubMed Central for supplementary material.

\section{Acknowledgments}

AMSM thanks the Office of Research and Sponsored Programs at Midwestern University for funding and Mary L. Hall for expert technical assistance. EA gratefully acknowledges the financial support of the GAANN and SCORE Programs of the University of Puerto Rico. We also thank Jan Vicente and the crew of the R/V Sultana for providing logistic support during the sponge collection. Financial support from a NIH-SC1 Award to ADR (Grant 1SC1GM086271-01A1) is gratefully acknowledged.

\section{References and notes}

1. Mayer AMS. Medicina (B Aires). 1998; 58:377. [PubMed: 9816700]

2. Mayer AMS, Oh S, Ramsey KH, Jacobson PB, Glaser KB, Romanic AM. Shock. 1999; 11:180. [PubMed: 10188770]

3. Hamberg M, Svensson J, Samuelsson B. Proc Natl Acad Sci USA. 1975; 72:2994. [PubMed: 1059088]

4. Giulian D, Corpuz M, Richmond B, Wendt E, Hall ER. Neurochem Int. 1996; 29:65. [PubMed: 8808790]

5. Huttemeier PC, Kamiyama Y, Su M, Watkins WD, Benveniste H. Prostaglandins. 1993; 45:177. [PubMed: 8430228]

6. Tassoni D, Kaur G, Weisinger RS, Sinclair AJ. Asia Pac J Clin Nutr. 2008; 17:220. [PubMed: 18296342]

7. König GM, Wright AD. J Org Chem. 1996; 61:3259.

8. Chang CWJ, Patra A, Baker JA, Scheuer PJ. J Am Chem Soc. 1987; 109:6119.

9. Trimurtulu G, Faulkner DJ. J Nat Prod. 1994; 57:501. [PubMed: 8021650]

10. Fusetani N, Yasumuro K, Kawai T, Natori T, Brinen L, Clardy J. Tetrahedron Lett. 1990; 31:3599.

11. Hirota H, Tomono Y, Fusetani N. Tetrahedron. 1996; 95:2359.

12. Ciavatta ML, Fontana A, Puliti R, Scognamiglio G, Cimino G. Tetrahedron. 1999; 55:12629.

13. Wratten JS, Faulkner DJ, Hirotsu K, Clardy J. Tetrahedron Lett. 1978:4345.

14. Avilés E, Rodríguez AD. Org Lett. 2010; 12:5290. [PubMed: 20964325]

15. Greco A, Ajmone-Cat MA, Nicolini A, Sciulli MG, Minghetti L. J Neurosci Res. 2003; 71:844. [PubMed: 12605411]

16. Ajmone-Cat MA, Nicolini A, Minghetti L. J Neurosci Res. 2001; 66:715. [PubMed: 11746392]

17. Fiebich BL, Lieb K, Hull M, Aicher B, van Ryn J, Pairet M, Engelhardt G. Neuropharmacology. 2000; 39:2205. [PubMed: 10963764]

18. Mayer AMS, Hall ML, Lynch SM, Gunasekera SP, Sennett SH, Pomponi SA. BMC

Pharmacology. 2001; 5:6. [PubMed: 15762999] 


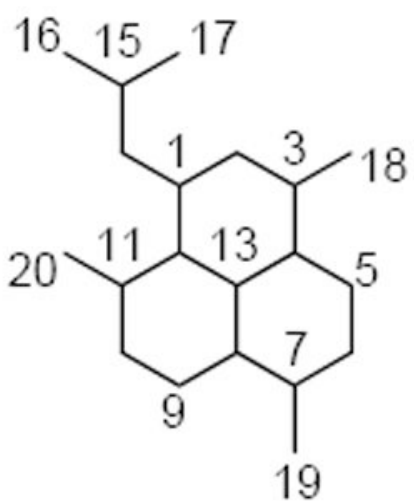

Amphilectane skeleton

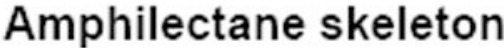<smiles>[C-]#[N+]C(C)(C)C[C@H]1C[C@H](C)[C@@H]2CC[C@@](C)([N+]#[C-])[C@@H]3CCC(=C)[C@H]1[C@@H]23</smiles>

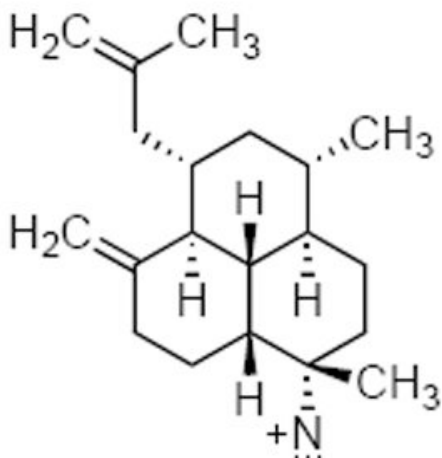
III 1<smiles>C=[N+][C@]12CCC(=C)[C@@H]3[C@@H](CC(C)(C)NC=O)C[C@@H](C)[C@H](CC[C@H]1C)[C@H]32</smiles>

4<smiles>[C-]#[N+]C(C)(C)C[C@H]1C[C@@H](C)C2CC[C@H](C)[C@]3([N+]#[C-])CCC(=C)[C@@H]1[C@H]23</smiles>

2<smiles>CCCCCCCC(=O)N1CCC1=O</smiles><smiles>[C-]#[N+][C@]12CCC(=C)[C@@H]3[C@@H]1[C@H](CC[C@@H]2C)[C@@H](C)C[C@@H]3CC(C)(C)C</smiles>

5

Figure 1.

Amphilectane-based isocyanides isolated from the Caribbean marine sponge Hymeniacidon sp. 


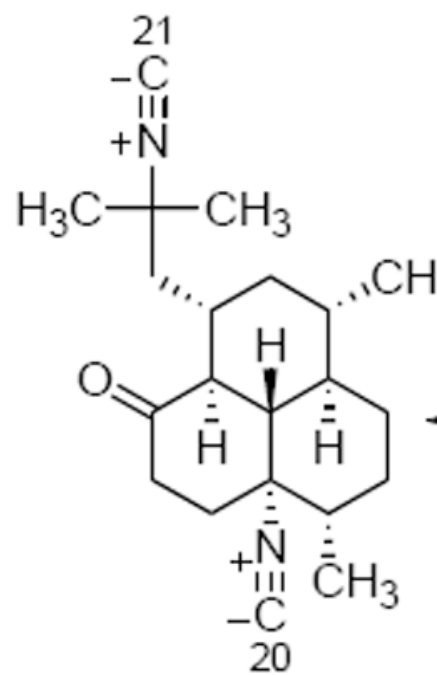

6

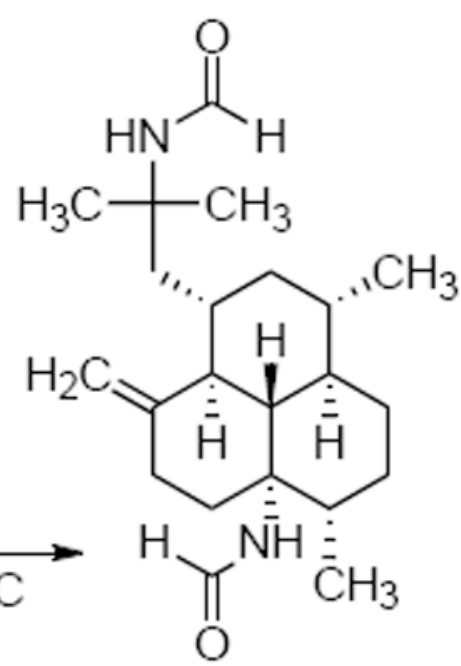

7

Scheme 1.

Preparation of semi-synthetic analogs 6 and 7 from (-)-8-15-diisocyano-11(20)amphilectene (2). 


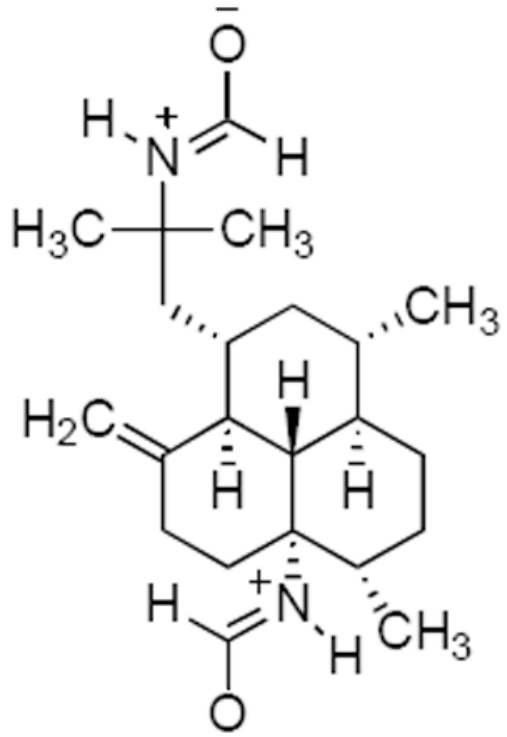

$7 a$

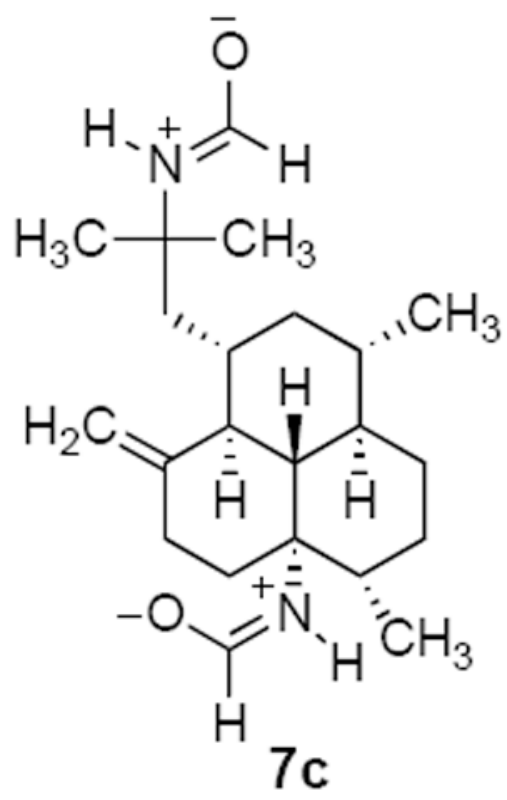<smiles>C=C1CC[C@]2(N=CO)C[C@H](C)CC[C@H](C)[C@H]2[C@H]1CC(C)(C)[NH+]=C(O)O</smiles>

$7 b$

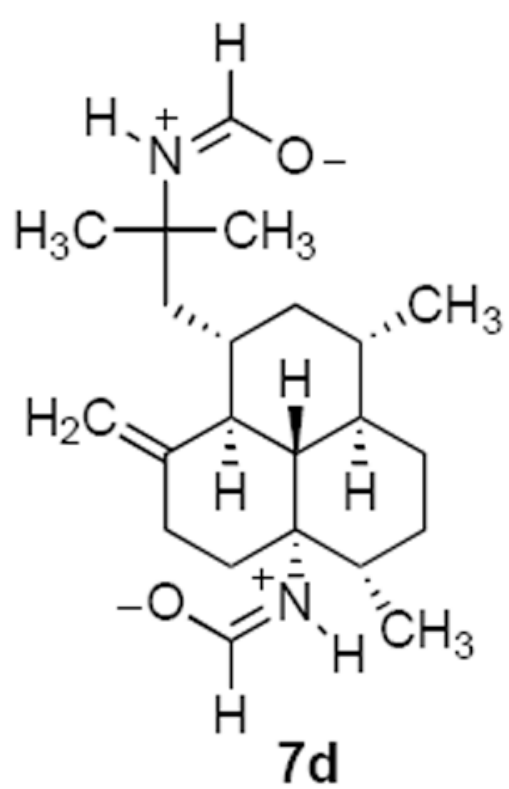

Scheme 2.

Structures for the four possible rotational isomers for compound 7 detected by NMR spectroscopy. 
Table 1

Anti-neuroinflammatory activity of Hymeniacidon sp. amphilectane metabolites ${ }^{a}$

\begin{tabular}{llll}
\hline Compound & $\begin{array}{l}\mathbf{O}_{2}^{-} \\
\mathbf{I C}_{\mathbf{5 0}}[\mu \mathrm{M}]\end{array}$ & $\begin{array}{l}\mathbf{T X B}_{2} \\
\mathbf{I C}_{\mathbf{5 0}}[\mu \mathrm{M}]\end{array}$ & $\begin{array}{l}\mathbf{L D H}_{50} \boldsymbol{b} \\
{[\boldsymbol{\mu M}]}\end{array}$ \\
\hline $\mathbf{1}$ & $>10$ & 1.72 & $>10$ \\
$\mathbf{2}$ & $>10$ & 0.23 & $>10$ \\
$\mathbf{3}$ & $>10$ & 0.20 & $>10$ \\
$\mathbf{4}$ & $>10$ & 1.48 & $>10$ \\
$\mathbf{5}$ & $>10$ & 4.69 & $>10$ \\
$\mathbf{6}$ & $>10$ & 1.43 & $>10$ \\
$\mathbf{7}$ & $>10$ & 3.14 & $>10$ \\
\hline
\end{tabular}

${ }^{a}$ Effect on rat microglia PMA $[1 \mu \mathrm{M}]$-stimulated release of $\mathrm{O}_{2}^{-}, \mathrm{TXB}_{2}$ and LDH. The anti-neuroinflammatory assay is described in Methods. Data corresponds to 2-4 independent experiments.

$b_{\mathrm{LDH} 50}$ represents the concentration of the compound that caused 50\% release of the total LDH content of microglia cells. LDH was measured as described in Methods. 